\title{
INDEX OF CONTRIBUTORS OF ARTICLES, SHORTER ARTICLES, COMMENTS AND NOTES
}

\author{
(articles are indicated in bold page numbers)
}

AdDo, Michael K., Are Judges Beyond Criticism under Article 10 of the European Convention on Human Rights?

ANDEnas, MAds, IV. Insurance and Banking

ARROwsMrth, SUE, Towards a Multilateral Agreement on Transparency in Government Procurement

BARKer, J. CrAia, II. State Immunity, Diplomatic Immunity and Act of State: A Triple Protection against Legal Action?

Benuamin, JoANNA, Determining the Situs of Interests in Immobilised Securities

BlokKer, Niels and MULLER, SAM, The 1996 Elections to the Intemational Court of Justice: New Tendencies in the Post Cold War Era?

Brentford, Philip, Constitutional Aspects of the Independence of the European Central Bank

Brigos, Adrlan, In Praise and Defence of Renvoi

Chan, Johannes M. M., Hong Kong's Bill of Rights: Its Reception of and Contribution to International and Comparative Jurisprudence

Chesterman, Simon, Last Rights: Euthanasia, the Sanctity of Life, and the Law in the Netherlands and the Northern Territory of Australia

Cox, Marcus, The Right to Return Home: International Intervention and Ethnic Cleansing in Bosnia and Herzegovina

Davies, Peter G. G., I. Global Warming and the Kyoto Protocol

De KAgenecx, Amelia and Pinel, CyreI, The Joint Convention on the Safety of Spent Fuel Management and on the Safety of Radioactive Waste Management

Dutson, Stuart, The Infringement of Foreign Intellectual Property Rights-A Restatement of the Terms of Engagement

EDoe, Peter W., The European Court of Human Rights and Religious Rights

EnChelmaier, Stefan, Il. Agriculture, Fisheries and Environment

Evans, ANDrew, European Union Decision-Making. Third States and Comitology

GARDINER, RICHARD, Revising the Law of Carriage by Air. Mechanisms in Treaties and Contract

Gilbert, Geoff, I. The Northern Ireland Peace Agreement, Minority Rights and Self-Determination

Hampson, Francoise J., The International Criminal Tribunal for Yugoslavia and the Reluctant Witness

KNOFEL, SUSANNE, EC Legislation on Conflict of Laws: Interactions and Incompatibilities Between Conflicts Rules

LANDO, OLE, Dicey \& Morris, The Conflict of Laws: A Review

LANe, Robert, III. Competition

Lonbay, Julan, I. Free Movement of Persons, Recognition of Qualifications, and Worting Conditions

Mclachlan, CAMPBEL, The Jurisdictional Limits of Disclosure Orders in Transnational Fraud Litigation

MCMAhON, Joseph A., International Agricultural Trade Reform and Developing Countries: The Case of the European Community

Mancero-Bucheli, Gabriela, Anti-Competitive Practices by Private Undertakings in Ancom and Mercosur: An Analysis from the Perspective of EC Law

Michael, Michael and Ridout, Arnold, I. Customs, Excise Duties and Value Added Tax

Mollerson, Rein, NATO Enlargement and the NATO-Russian Founding Act: The Interplay of Law and Politics

MoIr, LINDSAY, The Historical Development of the Application of Humanitarian Law in Non-International Armed Conflicts to 1949

Mumford, S. E., The Judicial Resolution of Disputes Involving Children and Religion 
980 Index of Contributors of Articles, Comments and Notes [VoL. 45

O'Keefe, Rooer, The "Right to Take Part in Cultural Life" under Article 15 of the ICESCR

Okowa, Phoebe N., Case Concerning the Gabcrikovo-Nagymaros Project (Hungary v. Slovakia)

Prince, Peter, Bhopal, Bougainville and OK Tedi: Why Australia's Forum non conveniens approach is better

QuANe, Helen, The UN and the Evolving Right to Self-Determination

Reichert-Facilides, Daniel, Down the Danube: The Vienna Convention on the Law of Treaties and the case concerning the Gabcikovo-Nagymaros Project

Rodoer, BARry J., Ascertaining the Starutory Lex Locti Delicti: Certain Difficulties under the Private International Law (Miscellaneous Provisions) Act 1995

Samuel Geoffrey, Comparative Law and Jurisprudence

Schoenbaum, Thomas J., WTO Dispute Settlement: Priase and Suggestions for Reform

SpInk, PaUl and PetTy, Ross, Comparative Advertising in the European Union

TuRns, DAvID, II. The International Criminal Tribunal for the Former Yugoslavia: the Erdemovie Case

Van Hoecke, Mark and Warrington, Mark, Legal Cultures and Legal Paiadigms: Towards a New Model for Comparative Law

VeEDER, V. V., The Lena Goldfields Arbitration: The Historical Roots of Three Ideas

VRANken, MARtin, Duty to Rescue in Civil Law and Common Law: Les Extremes se Touchent

WALXER, NEIL, II. Justice and Home Affairs

WoOdufre, JoHN, The Evolution of a New NATO for a New Europe

YEE, SIENHO, Thoughts on the Interpretation of the Phrase "Treaties in Force" in Article 35(2) of the Statute of the International Court of Justice 


\section{SUBJECT INDEX}

(Covering articles, shorter articles, comments and notes, ICJ cases and current developments; page numbers in bold type indicate articles or the first page of a main entry)

Agriculture

international trade

632

Air Transport

carriage conditions

Warsaw Convention, revision of protocols

Arbitration

supplementary conventions 303

awards

non-recognition

expropriation

general principles of law

international

747

procedure

arbitration clause, separability

"Kompetenz-Kompetenz" 785

State party, USSR

747

withdrawal

778

Australia

Euthanasia

Banking

European Central Bank

transnational fraud litigation

private international law, immobilised securrities

\section{Children}

religious upbringing, divorce

Choice of Forum forum non conveniens

Australia

Bhopal disaster

United Kingdom

United States

Choice of Law

$\begin{array}{ll}\text { Great Britain } & 205 \\ \text { lex loci delicti } & 205 \\ \text { personal injury cases } & 206 \\ \text { professional negligence cases } 209 \\ \text { property damage cases } & 206 \\ \text { unknown torts/delicts } & 209 \\ \text { renvoi } & \mathbf{8 7 7}\end{array}$

Comparative law

jurisprudence

legal mentalites

legal theory

legal cultures

legal doctrine

scientific model
Competition law
agreements
concerted practices $\quad 156$
procedure 169
Criminal law
accident victims 934
duty to rescue $\quad 936$
International Criminal Tribunal for the Former Yugoslavia $\quad 50$
Criminal procedure
International Criminal Tribunal for the Former Yugoslavia $\quad 50$
Divorce

children, religious upbringing 117

Environment

nuclear safety

radioactive waste $\quad 409$

spent fuel 409

Ethical law

euthanasia $\quad 362$

Australia 384

Netherlands 375

European Community

agriculture $\quad 632$

constitutional aspects 75

European Central Bank 81

economic independence $\quad 100$

legal independence $\quad 88$

political independence 105

international trade

developing countries $\quad 632$

monetary policy 102

European Convention on Human

Rights

expression, freedom of $\quad \mathbf{2 5}$

religious rights

European Union

decision making, comitology 257

Coreper 270

experts working groups $\quad 271$

lobbying bodies 267

management committees 273

programme committees $\quad 274$

standard bodies 267

conomic law 286

harmonisation $\quad 266$

liberalisation 264

extemal relations $\quad 257$

institutional law 260 
Family law

children

117

religion

117

Freedom of Expression

European Convention on Human

Rights judiciary, criticism of

425

Hong Kong

Bill of Rights

306

civil and political rights

306

Humanitarian law

Bosnia and Herzegovina

599

customary laws of war domestic conflicts

337

ethnic cleansing, reversal of

599

Dayton Agreement

603

Geneva Conventions

354

Art. 3

355

Human Rights

civil and political rights

fair trials

lesser penalties, right to

332

public life, right to participate

in

European Convention. See

European Convention on Human Rights

freedom of religion, children 133

Hong Kong Bill of Rights

306

International Covenant on Economic, Social and Cultural

Rights

904

culture as a way of life $\quad 916$

"high" culture 906

"popular" culture $\quad 912$

Self-determination $\quad \mathbf{5 3 7}$

decolonisation $\quad 547$

non-colonial $\quad 558$

UN Charter $\quad 539$

Intellectual property

infringement of foreign rights private international law

659

659

International Court of Justice

judiciary, election of

211 procedure

212

Statute non parties, locus standi

884

International Criminal Tribunal for

the Former Yugoslavia

procedure

reluctant witnesses

International Organisations

$\begin{array}{cc}\text { ANCOM } & 149 \\ \text { antitrust law } & 152 \\ \text { Latin America } & 149 \\ \text { MERCOSUR } & 149 \\ \text { antitrust law } & 152\end{array}$

International Trade

agriculture
International Trade-cont.

ANCOM

antitrust law

European Community and developing countries

632

Government procurement $\quad \mathbf{7 9 3}$

Latin America

149

MERCOSUR

149

World Trade Organisation $\quad 647$

Government procurement 793

Jurisprudence. See Legal Philosophy

Legal Philosophy

comparative law

817

Medical law

euthanasia

362

Australia $\quad 384$

Netherlands $\quad 375$

Netherlands

euthanasia

375

North Atlantic Treaty Organisation

(NATO)

174,192

enlargement

180,192

Euro-Atlantic Partnership Council

Former Yugoslavia

inter-institutional co-operation 191

NATO-Russian Founding Act 192

North Atlantic Co-operation Council

175

Western European Union 188

Private International Law

banking

fraud litigation

immobilised securities

choice of law, see Choice of Law

Dicey and Morris, review 394

EC Legislation

consumer protection $\quad \mathbf{4 4 0}$

employee protection $\quad 444$

transport

forum. See Choice of Forum

intellectual property

lex situs

renuoi

444

transnational disclosure orders

659

950

877

Russia

NATO

192

Tort

accident victims

934

duty to rescue

Western European Union

NATO

936

World Trade Organisation

Agreement on Government

Procurement

participation

transparency

dispute settlement

competence

188

private party access 


\section{INDEX OF CASES NOTED}

(Covering articles, shorter articles, comments and notes; page numbers are to the first reference to a case in any given article)

Airdale NHS Trust $v$. Bland [1993] A.C. 789

Attomey General v. Lee Kwong-Kut (1993) 3 H.K.P.L.R. 72

Attorney General v. Ming Pao Newspapers Ltd (1995) 4 H.K.P.L.R. 621 (Mag); (1995) 5 H.K.P.L.R. 13 (CA); (1996) 6 H.K.P.L.R. 103 (PC)

Barclays Bank plc v. RBS Advanta, The Times, 8 Feb. 1996

Barford v. Denmark Eur.Ct.H.R. Ser.A.149 (1989), (1991) 13 E.H.R.R. 493

Bridges v. California 314 U.S. 252 (1941)

British South Africa Company v. Companhia de Mocambique [1892] 2 Q.B. 358; [1893] A.C. 602

Buttes Gas \& Oil Co. v. Hammer [1975] 1 Q.B. 557

Case C-3/95 Reiseburo Broede v. Gerd Sandker [1996] E.C.R. I-6511

Cases C-74/95 and C-129/95 Criminal Proceedings v. X [1996] E.C.R. I-6609 229

Case C-101/94 Commission v. Italy [1996] E.C.R. I-2691

Case C-164/94 Georgios Aranitis v. Land Berlin [1996] E.C.R. I-135

Case C-177/94 Lloyd's of London v. Gianfranco Perfli [1996] E.C.R. I-161

Case C-273/93 Commission v. Luxembourg [1996] E.C.R. I-3207

Case C-278/94 Commission v. Belgium [1996] E.C.R. I-4307

Case C-344/95 Commission v. Belgium [1997] E.C.R. I-1035

Case concerning the Gabcikovo-Nagymaros Project

Chabot case, Netherlands Supreme Court, 21 June 1994, [1994] Nederlandse Jurisprudentie 656

Companie des Messageries maritimes Cass. civ. 24 Dec. 1924, D. 125, 120

Coins Control Ltd $v$. Suzo International (UK) Ltd [1997] 3 All E.R. 45

Criminal proceedings against Rafael Ruiz Bernaldes [1997] E.C.R. I-1829

Dagi and Others $v$. BHP Supreme Court of Victoria, 22 Sept. 1995, unrep.

Fort Dodge Animal Health Ltd and Others $v$. Akzo Nobel NV and Another (unrep., 27 Oct. 1997, CA

French Republic v. Commission of the European Communities [1997] E.C.R. I-1627

Gala v. Preston (1991) 172 C.L.R. 243

Garrison v. State of Louisiana 379 U.S. 64 (1964)

Germany v. European Parliament and Council [1997] E.C.R. I-2405

In re Union Carbide Corp. Gas Plant Disaster at Bhopal India in December, 1984, 634 F.Supp. 842

Kokkinakis v. Greece (1994) 17 E.H.R.R. 397

Kwan Kong Company Lid v. Town Planning Board (1995) 5 H.K.P.L.R. 261

Lee Miu-Ling v. Attorney General (1995) 5 H.K.P.L.R. 585

MacShannon v. Rockware Glass [1978] A.C. 795

Manoussakis and Others v. Greece (1996) 23 E.H.R.R. 387 (C.)

McDonald's v. Burger King [1986] F.S.R. 45

Oceanic Sun Line v. Fay (1988) 165 C.L.R. 197

Otto-Preminger-Institut v. Austria (1994) 19 E.H.R.R. 34 (C.)

Pearce v. Ove Arup Partnership Lid [1997] Ch. 293

Piper Aircraft Co. v. Reyno 454 U.S. 235 (1981)

Prager and Oberschlick v. Austria Eur.Ct.H.R. Ser.A.313(1994), (1996) 21 E.H.R.R. 1

Propend Finance Pty Ltd v. Alan Sing and The Commissioner of the Australian Federal Police judgment of 17 April 1997

R. v. Director of Immigration, ex p. Wong King-lung (1993) 3 H.K.P.L.R. 253

R. v. Kopyto 47 D.L.R. (4th) 213 (1987)

R. v. Man Wai-keung (No. 2) (1992) 2 H.K.P.L.R. 164

R. v. Sin Yaur Ming (1991) H.K.P.L.R. 88; [1992] 1 H.K.C.L.R. 127 
R. v. Town Planning Board, ex parte Kwan Kong Company Ld (1995) 5 H.K.P.L.R. 261

Sociéte Civile Immobilière Parodi v. Banque H. Albert de Bary et Cie [1977] E.C.R. I-3899

Spiliado Maritime Corp. v. Cansulex LId [1987] A.C. 460

Tam Hing Yee v. Wu Tai-wai (1991) 1 H.K.P.L.R. 261

The Atlantic Star [1974] A.C. 436

Valsamis v. Greece (1997) 24 E.H.R.R. 294

Vodafone Group ple v. Orange Personal Communications Services Ltd, The Times, 31 Aug. 1996

Voth v. Manildra Flour Mills (1990) 171 C.L.R. 538

Wingrove v. United Kingdom (1997) 24 E.H.R.R. 1 
Alison, J. W. F. A Continental Distinction in the Common Law-A Historical and Comparative Perspective on English Public Law (Jane Convery)

Amar, Akhil Reed. The Constitution and Criminal Procedure: First Principles (Colin Warbrick)

Anaya, S. James. Indigenous Peoples in International Law (Patrick Thornberry)

Andreopoulos, George J. (Ed.). Genocide: Conceptual and Historical Dimensions (Mark Levene)

Balkin, R. P. and Davis, J. L. R. Law of Torts (2nd edn) (W. V. H. Rogers)

Baumgartl, Bernd. Transition and Sustainability (Francis McManus)

Beatson, Jack and Tridimas, Takis (Eds). New Directions in European Public Law (James Kingston)

Beck, Robert J., Arend, Anthony Clark and Vander Lugt, Robert D. (Eds). International Rules-Appraaches from Intemational Law and International Relations (Colin Warbrick)

Bethlehem, Daniel and Weller, Marc (Eds). The "Yugoslav" Crisis in Intemational Law: General Issues. Part I. (Dino Kritsiotis)

Blake, G. et al (Eds). Intemational Boundaries and Environmental Security: Frameworks for Regional Co-Operation (A. E. Boyle)

Boyle, Alan and Anderson, Michael (Eds). Human Rights Approaches to Environmental Protection (Malgosia Fitzmaurice)

Chinkin, Christine and others (J. P. Gardner (Ed.)). Human Rights as General Norms and a State's Right to Opt Out-Reservations and Objections to Human Rights Conventions (Nigel S. Rodley)

Colaianni, Tea. European Works Councils (Erika Szyszczak)

Dagan, Hanoch. Unjust Enrichment: A Study of Private Law and Public Values (Hector L. MacQueen)

D'Amato, Anthony. Intemational Law Studies: Collected Papers (Surya Subedi)

Daudet, Yves (Ed.). Les Nations Unies et Le Developpement Social Intermational (Peter Slinn)

David, E. Principes de Droit des Conflits Amés (Istvan Pogany)

Dean, Meryll. Japanese Legal System: Text \& Material (Sian Stickings)

Degan, V. D. Sources of Intemational Laws (Rein Mallerson)

de Hoogh, Andre. Obligations Erga Omnes and International Crimes: A

Theoretical Inquiry into the Implementation and Enforcement of the Intemational Responsibility of States (Hazel Fox)

Edge, P. W. Manx Public Law (N. M. Cordwell)

Eyffinger, A. The Intemational Court of Justice (Malcolm D. Evans)

Fleck, Dieter (Ed.). The Handbook of Humanitarian Law in Amed Conflict (Dominic McGoldrick)

Ganci, Potthard. Intemational Pollution at Sea (Thomas J. Schoenbaum)

Gardner, J. P. (Ed.). Citizenship-the While Paper (Paul Robertshaw)

Geddes, Andrew C. Protection of Individual Rights under EC Law (Andrew J. Cunningham)

Green, L. C. The Contemporary Law of Armed Conflict (Istvan Pogany)

Guislain, Pierre. The Privatization Challenge (John McEldowney)

Hatchard, John, Huber, Barbara and Vogler, Richard (Eds). Comparative Criminal Procedure (Inneke Onsea)

Hathaway, James C. (Ed.). Reconceiving International Refugee Law (Michael Byers)

Henckaerts, J.-M. (Ed.). The International Status of Taiman in the New World Order (A. E. Boyle)

Henkin, Louis. Foreign Affairs and the United States Constitution (Stephen C. Neff)

Herget, James E. Contemporary German Legal Philosophy (Norman S. Marsh)

Huang. Philip C. C. Civil Justice in China: Representation and Practice in the Qing (Perry Keller)

Hunnings, Neville March. The European Courts (L. Neville Brown) 
Jaffey, A. J. E. Topics in Choice of Law (Edwin Peel)

Kariotis, Theodore C. (Ed.). Greece and the Law of the Sea (Geoffrey Marston)

Korah, Valentine. Technology Transfer Agreements and the EC Competition Rules (David T. Keeling)

Kingston, James and Whelan, Anthony, with Bacik, Ivana. Abortion and the Law (Padraic Taylor)

Kiss, Alexandre Charles and Shelton, Dinah. Manual of European Environmental Law (Donald A. Reid)

Klabbers, Jan. The Concept of Treaty in Intermational Law (Perry Keller)

Krieger, Heike (Ed.). East Timor and the Intemational Community: Basic Documents (Iain Scobbie)

Lapidoth, Ruth. Autonomy: Flexible Solutions to Ethnic Conflicts (Colin Warbrick)

Loyd, Loma. Peace Through Law: Britain and the International Court in the 1920 (R. Y. Jennings)

London, Caroline and Llamas, Michael. EC Law on Protection of the Environment and the Free Movement of Goods (Ludwig Krber)

MacCormick, D. Neil and Summers, Robert S. (Eds). Inserpreting Precedents: $A$ Comparative Study (Elspeth Reid)

MoGonagle, Marie (Ed.). Law and the Media: The Views of Joumalists and Lawyers (Clive Walker)

Markesinis, B. S., Lorenz, W. and Dannemann, G. The German Law of Obligations. Vol. 1: The Law of Contracts and Restitution: A Comparative Introduction (Antje Kunst)

Matringe, Jean. Tradition at Modemite dans la Charte Africaine des Droits de l'Homme et des Peuples: Erude de contenu normatif de la Charte et de son apport d la theorie du droit intemational des droits de l'homme (Rachel Murray)

Mattei, Ugo. Comparative Law and Economics (John Bell)

Meijers, H. et al Democracy, Migrants and Police in the European Union- The 1996 JGC and Beyond (Vatsamis Mitsilegas)

Mendlovitz, Saul H. and Weston, Burns H. (Eds). Preferred Futures for the United Nations (Stephen C. Neff)

Mitrakas, Andreas. Open EDI and Law in Europe (John Dickie)

Mousse Jean. Le Contentieux des Organisations Intemationales et de l'Union Europeenne (Henry G. Schermers)

Muller, A. S., Raic, D and Thuránszky, J. M. (Eds). The International Court of Justice: Its Future Role after Fifty Years

Murphy, Sean D. Humanitarian Intervention: The United Nations in an Evolving World Order (Colin Warbrick)

Nascimbene, Bruno (Ed.). Nationality Laws in the European Union (Stratos Konstadinidis)

Nelken, David (Ed.). Comparing Legal Cultures (John Bell)

Niedobek, Matthias (trans. James Benn and Robert Bray). The Cultural Dimension in EC Law (Lynn E. Ramsay)

Peck, Connie and Lee, Roy S. (Eds). Increasing the Effectiveness of the International Court of Justice (J. G. Merrille)

Phelan, Diarmuid Rossa. Revolt or Revolution: The Constitutional Boundaries of the European Community (L. Neville Brown)

Piotrowicz, Ryszard W. and Blay, Sam K. N. The Unification of Germany in Intemational and Domestic Law (Sven Reckewerth)

Raworth, Philip. Foreign Trade Law of the European Union (Padraic Taylor)

Sunga, Lyal S. The Emerging System of International Criminal Law: Developments in Codification and Implementation (Geoff Gilbert)

Swadling. William (Ed.). The Limits of Restitutionary Claims: A Comparative Analysis (Gerhard Dannemann)

Vandersanden, Georges and Dony, Marianne. La responsabilite des ctats membres an cas de diolation du droit communautaire, Etudes de droit communautaire at de droit national compart (Walter van Gervan) 